\title{
IDEATIONAL INTERSEMIOTIC RELATION IN TEMPO'S MAGAZINE COVER REPRESENTING SETYA NOVANTO
}

\author{
Andriana Vita Nurjannah \\ Indonesia University of Education \\ andrianavita@upi.edu
}

DOI : http://dx.doi.org/10.18326/rgt.v11i2.192-209

\begin{abstract}
Submission
ABSTRACT

Track:

Received:

$29 / 04 / 2018$

Magazine cover is an image that accommodates the readers with a critical value information of a news story. The essence of a particular story is able to be represented in a single page of

Final Revision: magazine cover. It indeed covers not only the surface or real

$25 / 11 / 2018$ meanings, but deeper meaning soon to be analysed by the readers.

Available online: The recent politician case relating Setya Novanto is one of the trending topic in news event as it impacts in the massive reaction

$01 / 12 / 2018$ from the Indonesian citizens, like making particular memes and even an android game. In this case, the illustrators of one of news magazine, Tempo, have to make a cover representing that event through the visual and verbal composition. Therefore, despite his

Corresponding Author: trial status, this research is aimed at examining the extended meaning depicted from his picture from one national media by

Andriana Vita

Nurjannah andrianavita@upi.edu $+6285647225745$ identifying visual and verbal elements in the image as the effort to reveal intersemiotic relation between those multimodal modes. This research employed qualitative method, by administering six covers published in 2017 representing Setya Novanto as the news topic. The image and text elements from the cover were identified based on one of metafunctions initially proposed by Halliday (1994), the ideational function. Thus, the intersemiotic analysis were done by relating the visual and verbal meanings (Royce, 1998, 1999, 2002, 2015).
\end{abstract}

Keywords: magazine cover, multimodal, intersemiotic

\section{INTRODUCTION}

Generally, people literally give value at something by its cover, no exception for the cover of a magazine. Thus, cover or the front part of a magazine plays a critical role in leading the readers' perception. A cover is usually designed meticulously so that one single page can accommodate the whole story. In this case, a cover does not only hold surface meaning but it 
also involves deeper meaning. Every single part of the elements, both visual and verbal, are specifically designed to meet the intended message.

Recently, an Indonesian politician, Setya Novanto became a trending topic in social media because of his case. What makes this case interesting is that it leads to unique responses from Indonesian citizens, like memes and an android game. Despite concerning his trial session, it is intriguing to know the perception of people regarding him and the case.

Thus, an analysis of the magazine cover which mainly reports him and his case was necessary since magazine is seen as the representation of some people's point of view. In addition, the cover can be an indicator of the different perspective in current issue in environment (Dodd, Foerch, and Anderson, 1998). Magazine cover is seen as the right means to deal with that since one of the functions is to catch the interest of the potential readers (Tseronis, 2015).

This paper is aimed at examining the extended meaning depicted from his picture from one national media to reveal intersemiotic relation between those multimodal modes. To achieve that goal, visual and verbal elements in the image must be identified. In this case, the visual elements relate to the participants pictured on the magazine cover, both animate and inanimate object, while the verbal elements associates to the headlines and the lexical items followed. In this paper, ideational metafunctions is the only metafunctions involved in identifying those multimodal modes, without breaking down those multimodal modes in interpersonal and textual metafunctions.

\section{Multimodal Analysis}

Most of printed news media, like news magazine, is filled not only with verbal but also visual means of communication which usually draws an illustration towards the story in verbal senses. It is apparently clear that the producers do not arrange the diverse images along with the writing on the text randomly, but it is full of semantic purposes (Royce, 2002). According Halliday (1994), those semantic purposes are able to be expressed through metafunctions.

There are three communication metafunctions: ideational, interpersonal, and textual. The first, ideational, concerns with the sign being the representation in the real life. While interpersonal is the connection of the signs available in the text, between the sign producer and receiver. And textual explores the sign which is more complex, relating the sign with the context. 
This paper only focusses on ideational metafunctions which represents what happens in the image and text which is also known as representational meaning (Kress and van Leuween, 2006). Therefore, even though that verbal and visual modes of communication adopt specific meaning-making resources to each particular mode, they also cooperate to realize meaning of intersemiotic relation and to create a clear multimodal text for the readers (Royce, 1998, 1999).

\section{Ideational Intersemiotic Relation}

The framework of Intersemiotic relation derives from the metafunctional form of communication initiated by Halliday. In achieving the objective of this paper, a framework proposed by Royce (1999) is used which is presented in Image 1. This framework derives from Halliday's metafunctional communication, relating the Visual Message Element (VME) and the lexical item. In this case, the VME is limited on participant, process, circumstance, and attributes which represents the ideational metafunction. The lexical item refers to the phrase or word of the text that is associated semantically with the VME's experiental meaning. Besides, it is clearly seen that there is a gap between a multimodal text which is then called Intersemiotic relation.

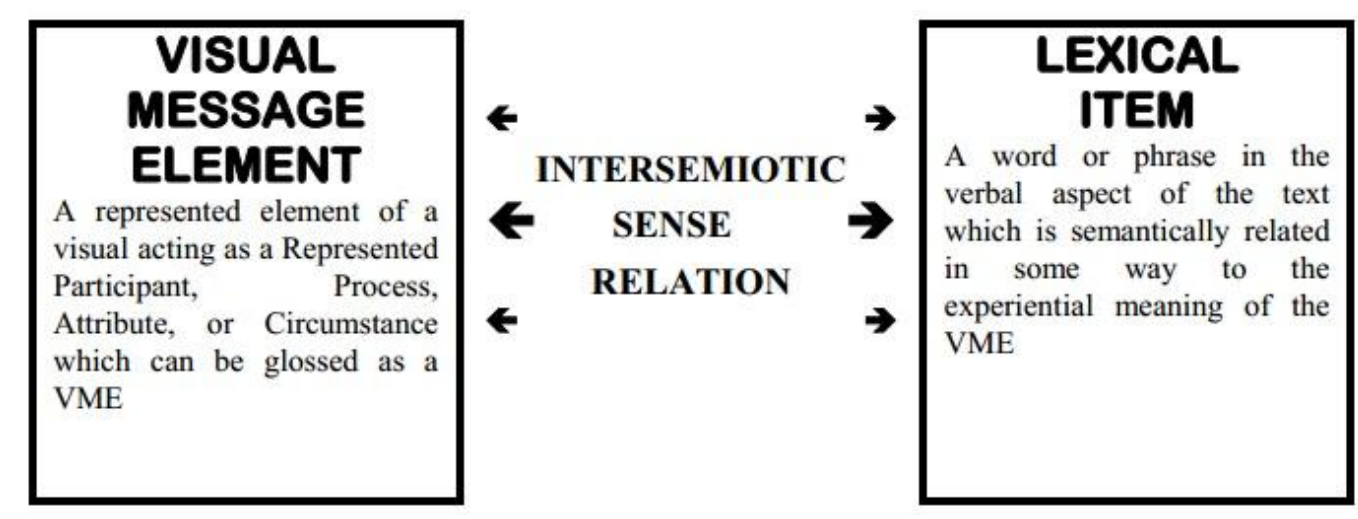

\section{Image 1 Intersemiotic Relation from Royce (1999)}

The type of intersemiotic relation would be analysed to get the picture of how the image producer makes use two semiotic resources in projecting the intended meaning and what impacts of that action. In this paper, the ideational is the only metafunctionals explained, which refers to tell 'what's going on' in the image. The starting point to break down the visuals is by identifying the participants represented in the image or the whole elements, both animate or inanimate. 
There are procedural steps in examining the ideational intersemiotic relation. In the first stage, the visual analysis was conducted. It was done by doing several steps. The initial step was done by identifying the image in connection with the portrayed participants (Identification), process (Activity), context (Circumstances), and participant's characteristics (Attributes). The second was by interpreting those aspects depending on the context of creation, situation, and history (Halliday, 1994; Royce 1998, 2002, 2015). Later, those aspects were assigned into Visual Message Element (VME) label.

In the second stage, the verbal modes were analysed by identifying each clause in the represented lexical items in which semantically related to each identified VME and later making lexical inventories of the verbal modes which are semantically reflected to the VMEs' experiental meaning.

In the last stage, the intersemiotic relation was analysed by some steps. First, it was done by identifying each clause in the inventory by considering the VME. Second, the semantic relationship was interpreted between each VME and the verbal item by classifying the relation of Repetition, Antonymy, Synonymy, Meronymy, Hyponymy, and Collocation. Later, the verbal items were labelled as 'R', 'A', 'S', 'M', 'H', 'C'. Finally, the frequency and relations were interpreted.

The Intersemiotic relation in terms of Ideational examines at how the visual resources semantically link to the verbal resources, in which both visual and verbal elements can work complementarily to convey meaning. There are various lexico-semantic means of communication that links the logical and experiential content projected in the multimodal modes (Royce, 1998, 2002). They are presented as follows:

a. Repetition $(\mathrm{R})$ : identical relations

An example of Intersemiotic Repetition is realized when the visual contains the figure of Setya Novanto. (the VME is explained as Setya Novanto) and the lexical item "Setya Novanto" also occurs in the verbal element of the text.

b. Synonymy $(\mathrm{S})$ : similarity relations

An example of Intersemiotic Synonymy is when a visual represents the figure of Setya Novanto and the lexical item in verbal aspect is realized with the wording "House of Representative's Chairman".

c. Antonymy (A): opposite relations 
An example of Intersemiotic Antonymy is when a graphic visual shows a condition of being locked up and the lexical item in the verbal text is accommodated with the word "free".

d. Meronymy (M): part-whole relations

An example of Intersemiotic Meronymy is when a visual represents a table listing the corruption in Indonesia and the verbal item shows Electronic Identity Card associating specific sector in Indonesia's corruption.

e. Hyponymy $(\mathrm{H})$ : class-subclass relations

An example of Intersemiotic Hyponymy is realized when a visual showing Indonesian politicians and the lexical item of the text is accommodated with wording "Setya Novanto".

f. Collocation(C): expectancy relations

The example of Intersemiotic Collocation is when the visual represents the setting of court, and the lexical item is realized with the wording suspect, judge, prosecutor.

\section{Tempo's Magazine Cover}

A cover of a magazine plays a critical role because frankly it works to capture the readers' attention (Sumner and Rhoades, 2006 in Jenkins and Tandoc, 2015). To gain this objective, the publisher of a magazine will certainly create a sophisticated cover design that can persuade the readers. Moreover, the cover is considered as the face of the print that functions as the image building of a magazine (Losowsky, 2007 in Jenkins and Tandoc, 2015). Hence, to maintain the image of a magazine, the publisher will utilize the similar style in presenting the news on the cover.

Besides, magazine cover also serves as cultural markers, which demonstrates the cultural and social fact happened in the area where the magazine is published (Abrahamson et al., 2003). Thus, it can be a reminder of the social phenomena in the societies. In addition, the objects in a magazine cover, either living or not, can be a symbol of culture as it is exhibited, reprinted, and immortalized in books, displays, or other magazines (Jenkins, 2015).

Tempo magazine is one of news magazine from Indonesia which is known for its critical thinking in reporting a news. It was banned for several times because of its 'judgement' over 
certain cases. The unique thing from this magazine is the caricature for the cover page as the visual resources.

The caricature serves as superportraits, making it more recognisable than the common photograph (Benson and Perret 1994; Rhodes and Tremewan 1994; Rhodes at al., 1987). It provides exaggerated accent to the people or things caricatured (Rosielle and Hite, 2009). Royce (2015) adds that caricature employs prominent role in visual element. Besides, caricatures increase the faces' distinctiveness (Rhodes et al., 1997) so that the readers are able to picture who is being described accurately. Thus, the use of caricature in portraying the visual mode is not merely for aesthetic purpose but it is indeed purposely design for giving accentuated meaning.

\section{METHODS}

This research utilized qualitative descriptive method, by employing six covers published in 2017, from January to November. The Figure 1 is the newest magazine, while the last figure is the latest one. Purposive sampling which is the type of sampling technique that selects the objects intentionally based on particular purpose was employed to maintain those six covers. The selected images were the covers for published magazine which employ Setya Novanto as the news topic. This was done considering the aims of the study, examining the extended meaning depicted from Setya Novanto's figure by revealing Intersemiotic relation between those multimodal modes. The image and text elements from the cover were identified based on one of metafunctions initially proposed by Halliday (1994), the ideational function. Thus, the intersemiotic analysis was done by relating the visual and verbal meanings (Royce, 1998, 1999, 2002).

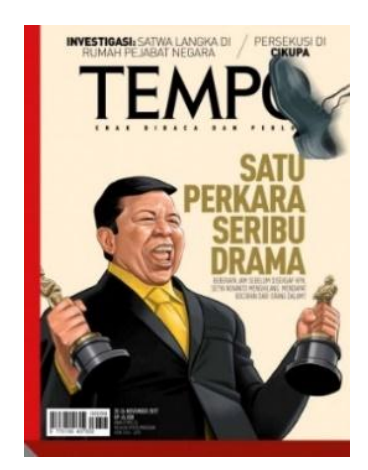

Figure 1

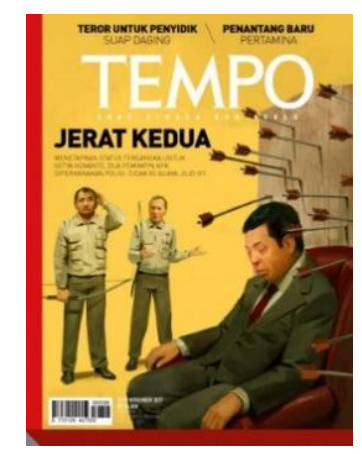

Figure 2

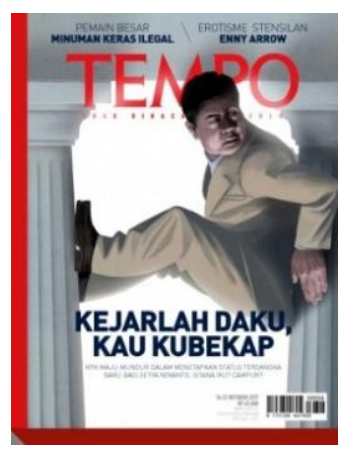

Figure 3 


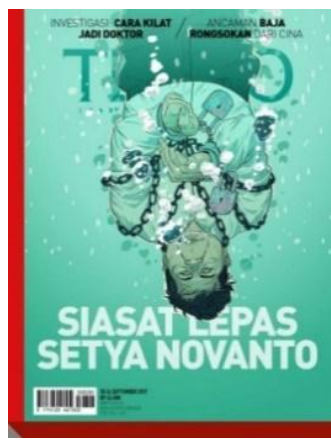

Figure 4

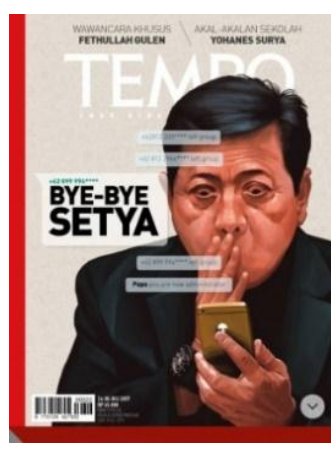

Figure 5

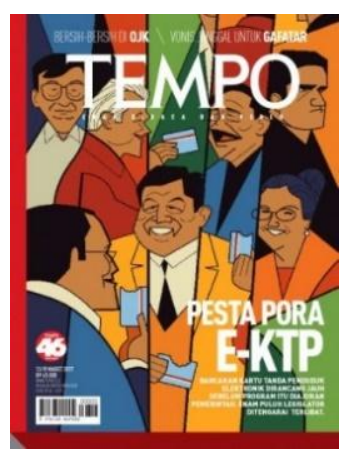

Figure 6

Table 1 Selected Magazine Covers

\section{DISCUSSION}

This section represents the finding and discussion of the research. It first describes the visual and verbal modes from each Figure. Later, the Intersemiotic relation is examined. The caricatures represented in each Figure are the typical visual modes in Tempo Magazine.

\section{Figure 1}

\section{Visual Analysis}

The Identification, representing who or what is depicted in the image, portrays a facial feature caricature of a well-known politician, Setya Novanto, who is known because of his case. his popularity is proved by the actions by the citizen like creating android game. The visual also displays two trophies which is clearly denoted as winning. The physical appearance of the trophies is distinct, representing the trophies used as the symbol of best actor from a movie. Moreover, the trophies are pictured more than one, meaning that is the best actor capable of achieving two trophies in one event. Thus, he is pictured of having good skill in acting.

There is also a flying shoe directing at him which denotes insult. This can further depict the lack of respect from the people around him. The interaction of these participants seems creating meaning that the man is the best actor of a movie, but not many people seem to like it as the existential of the flying shoe closing to him. The shoe has metaphorical meaning as the offensive action done.

Related to the action which takes place, or the Activity, it is quite clear that it portrays a man getting two trophies at once because of his skill. The impression conveyed is that he is great at acting (his skill) even though not many people seem dislike it as the representation of the flying shoe. 
The Attributes, relating to the characteristics and qualities of the participants, in this figure is shown in the man's facial expression, depicting satisfaction as he laughs in joy. In addition, the black suit he wears symbolizes position, wealth, power because of the expensive cost of the costume and because it is used for people in high social class. It reflects to his work, as a politician having great power and authority. The yellow shirt also emphasizes his position (power) in Golkar party.

From the Circumstances or the context, it can be seen that the man and the trophies are not just placed anywhere. By considering the suit he wears, the trophies, and the flying shoe, it can be interpreted that it happens in a stage, a place where actors usually receive trophies because of their act. The flying shoe accentuates this interpretation as the shoe comes from public space representing audience which can be depicted as citizen. He is being on the stage does not only have locative meaning but it carries metaphor meaning as the one being the spotlight (the centre of attention) since he was the House of Representative (HOR)'s Chairman.

\section{Verbal and Intersemiotic Analysis}

The analysis of verbal elements was done after the visual elements of the image being analysed. The verbal elements later are broken down into clauses so that each clause can be related to the identified VME having intersemiotic relations of Repetition, Antonymy, Synonymy, Meronymy, Hyponymy, and Collocation. In this case, the Attributes is subsumed to the process that having similar interpretation.

Table 4 Ideational Intersemiotic Relation

\begin{tabular}{|c|c|c|c|c|c|c|c|}
\hline & \multicolumn{3}{|c|}{ Represented participants } & Circumstances & \multicolumn{3}{|c|}{ Attributes } \\
\hline S's & $\begin{array}{c}\text { Setya } \\
\text { Novanto }\end{array}$ & $\begin{array}{l}\text { trophies } \\
\text { (good } \\
\text { acting) }\end{array}$ & $\begin{array}{l}\text { flying } \\
\text { shoe } \\
\text { (offensive } \\
\text { action) }\end{array}$ & $\begin{array}{c}\text { stage } \\
\text { (House of } \\
\text { Representative) }\end{array}$ & $\begin{array}{l}\text { laughing } \\
\text { (satisfied) }\end{array}$ & $\begin{array}{c}\text { suit } \\
\text { (position/ } \\
\text { power) }\end{array}$ & $\begin{array}{l}\text { yellow } \\
\text { shirt } \\
\text { (part of } \\
\text { Golkar) }\end{array}$ \\
\hline 1. & - & $\begin{array}{l}\text { thousand } \\
\text { dramas } \\
\text { (C) }\end{array}$ & - & - & - & - & - \\
\hline 2. & $\begin{array}{l}\text { Setya } \\
\text { (R) }\end{array}$ & - & $\begin{array}{l}\text { being } \\
\text { caught } \\
\text { (C) }\end{array}$ & - & - & $\begin{array}{l}\text { disappeared } \\
\text { (C) }\end{array}$ & - \\
\hline 3. & - & - & - & - & - & $\begin{array}{c}\text { leaks }(C) \\
\text { insiders }(C)\end{array}$ & - \\
\hline
\end{tabular}


By analysing these multimodal resources, the evidence of intersemiotic relation can be seen, as implied by a number of lexical items related to the news topic on Setya Novanto's case. As shown in table 4, there is a relation in which the lexical items intersemiotically repeat and collocate with the visual items. It is clear that there is repetition relation as the use of lexical item Setya and the use of Setya's representation as the visual item.

In addition, the trophies shown in the visual collocate with the wording dramas since there are many awarding events held by film industry that give appreciation (trophies) to the one having good act in his/ her drama. The other significant visual attribute is the flying shoe which collocates with the lexical item of being caught since the flying shoe in this case connotes offensive action. The intersemiotic relation is also seen from the Attributes in which the figure wears a black suit. In reality, he was the House of Representative's Chairman, having such a power and authority to get something not ordinary people can. This has collocation meaning with the lexical items leaks, insiders, and disappear. It is because his power enables him to have insiders to acquire information leaks so that he can disappear before getting caught.

\section{Figure 2}

\section{Visual Analysis}

The Identification in this second picture portrays a caricature image of a middle-aged man having facial representation figure of Setya Novanto. Not far from him, there are two middleaged men carrying bows as the foreground of the image. They are caricatured as two wellknown public figures that serves as the chief and vice chiefs of Corruption Eradication Commission (later CEC), Agus Raharjo and Saut Sitomorang respectively. As they hold bows, they seem confused as it is seen from their gestural act. In addition, there are 14 arrows landed around the sleeping man in which both the man and the arrows are positioned as the salience elements. There is also a plank depicted behind the sleeping man, connoting an object being the target, Setya Novanto as the target.

While the Activity seen from this visual communication is depicted from the bows and arrows. The men in uniform seem shooting the arrows using the bows to a man sitting in a couch. In this image, the man seems not bothered with the arrows as he sleeps comfortably and all the arrows are scattered around the man without hitting him. 
As for the Circumstances, the setting of this picture can be interpreted as in an office since there is a couch similar with the one in an office and the formal suit the man wears provide metaphor meanings as the officers do such a thing as the impact of what the man did at work.

The Attributes is depicted from the expression of the participants. The sleeping man symbolizes being in a peaceful condition although he is being targeted (the present of the arrows). The suit he wears emphasizes the power, having a high position in his office. While the two-people wearing uniform means that they work for an organisation representing Indonesia's Corruption Eradication Commission. They seem having such an authority to target someone/ something (bows). The arrows located around the sleeping man without hitting him even an inch reveals that he is the target that is hard to get.

\section{Verbal and Intersemiotic Analysis}

The intersemiotic relation is seen by relating the visual and verbal modes. In this case, the VME of Activity is included in Identification, while the Attributes is subsumed into the Identification except for the gestural acts of the two men represented in the text.

Table 7 Ideational Intersemiotic Relation

\begin{tabular}{|c|c|c|c|c|c|c|}
\hline & \multicolumn{4}{|c|}{ Represented participants } & \multirow{2}{*}{$\begin{array}{c}\text { Circumstances } \\
\text { office couch } \\
\text { (being } \\
\text { targeted } \\
\text { because his } \\
\text { office work) }\end{array}$} & \multirow{2}{*}{$\begin{array}{c}\begin{array}{c}\text { Attributes } \\
\text { (two } \\
\text { officers) }\end{array} \\
\text { look } \\
\text { confused } \\
\text { (being } \\
\text { confused } \\
\text { after } \\
\text { targeting } \\
\text { suspect) }\end{array}$} \\
\hline S's & $\begin{array}{c}\text { Setya } \\
\text { Novanto }\end{array}$ & $\begin{array}{c}\text { Agus } \\
\text { Raharjo and } \\
\text { Saut } \\
\text { Sitomorang } \\
\text { (CEC's } \\
\text { chiefs) }\end{array}$ & $\begin{array}{c}\text { bows and } \\
\text { arrows } \\
\text { (targeting } \\
\text { suspect) }\end{array}$ & $\begin{array}{c}\text { plank } \\
\text { (target) }\end{array}$ & & \\
\hline 1. & - & - & $\begin{array}{l}\text { accusation } \\
\text { (C) }\end{array}$ & - & - & - \\
\hline 2. & $\begin{array}{c}\text { Setya } \\
\text { Novanto } \\
\text { (R) }\end{array}$ & $\begin{array}{l}\text { Corruption } \\
\text { Eradication } \\
\text { Commission's } \\
\text { chiefs (C) }\end{array}$ & $\begin{array}{l}\text { convicting } \\
\text { (C) }\end{array}$ & $\begin{array}{l}\text { suspect } \\
\text { (S) }\end{array}$ & - & $\begin{array}{l}\text { were charged } \\
\text { with crime } \\
\text { (C) }\end{array}$ \\
\hline 3. & - & little lizard (S) & - & - & - & - \\
\hline
\end{tabular}

The intersemiotic relation is mostly on collocation, representing Agus Raharjo and Saut Sitomorang as the Corruption Eradication Commission's chiefs (the position they held), while 
little lizard (metaphoric term for CEC institution) has intersemiotic synonymy. The bows and arrows visual representation also collocates with lexical items accusation and convicting since they are related to the metaphoric meaning, targeting suspect. Besides, the attributes of two officers also intersemiotically collocates with lexical item "were charged with crime". In this second figure, the visual image of Setya Novanto is realised in the lexical items "Setya Novanto" having repetition relation. The plank behind the salient figure has intersemiotic synonymy with the word suspect, as the one being targeted.

\section{Figure 3}

\section{Visual Analysis}

The Identification from this image is a caricatured man as the representation of Setya Novanto, having the primary visual element in this text. The Activity from this third image is clearly seen as the man climbs the two supports of a building without using any tools to help him, being skilful. The visual metaphor from this cover is that the man is capable of doing something that not many people can, by doing an acrobatic movement as he climbs the supports of a building by himself. From the real context, he is having a legal case and being chased by the prosecutors. Thus, it connotes that he is powerful enough to hide from them.

The Circumstances in this case referring to the place, the accompanied person or the other fact presented in a picture. In this image, there are two white supports of a building which is akin to the one in Indonesia's State Palace. Thus, it can be inferred that the illustrator wants to depict government's role in this activity. Related to the Attributes, the picture denotes that he looks cautious as he looks behind him. This movement infers that he hides or waits for somebody (prosecutor) to come. Thus, it has metaphoric representation as having great ability to hide in public places as the existential of white supports connoting the State Palace. The figure in a suit also connotes power/ authority he has.

\section{Verbal and Intersemiotic Analysis}

The intersemiotic relation from Figure 3 has diverse relation compared to the previous images. The cautious gesture portraying hiding movement from prosecutors has intersemiotic antonym with the lexical catch, and intersemiotic collocation with suspect status. The participant is pictured both in visual and verbal modes, representing Setya Novanto, showing 
repetition and synonym relation. The collocation is proved in the verbal item $m e$ as he acts as the sole participant. In addition, the State Palace is depicted as having synonymy relation with the white supports of the building connoted as Indonesia's State Palace.

Table 10 Ideational Intersemiotic Relation

\begin{tabular}{|c|c|c|c|c|}
\hline S's & $\begin{array}{c}\text { Represented participants } \\
\text { Setya Novanto }\end{array}$ & $\begin{array}{c}\text { Circumstances } \\
\text { white supports } \\
\text { (Indonesia's } \\
\text { State Palace) }\end{array}$ & $\begin{array}{c}\text { Aooks cautious } \\
\text { (hiding from } \\
\text { prosecutors) }\end{array}$ & $\begin{array}{c}\text { Arown suit } \\
\text { (having power/ } \\
\text { authority) }\end{array}$ \\
1. & me (C) & - & catch (A) & - \\
\hline 2. & Setya Novanto (R) & - & suspect status (C) & - \\
\hline 3. & - & State Palace (S) & - & - \\
\hline
\end{tabular}

\section{Figure 4}

\section{Visual Analysis}

The Identification represented in Figure 4 is a caricature of a middle-aged man represented as Setya Novanto, being literally tied up by the chains and handcuffs. This contains metaphoric meaning as being restricted from doing whatever he wants. Actually, it also connotes as being punished or being in hard situation. The Activity seen from this visual mode is that he is being upside down in water while holding his breath. The condition of him being upside down metaphorically means that his life is being upside down, from having freedom to do anything into being locked up. In this caricature, his right-hand moves closing to the handcuffs in his left-hand. This movement can be described as the effort to escape.

For the Circumstances aspect, the aqua colour in background setting is obviously pictured as water surrounding the man. The water adds the hard situation being described previously. Moreover, such situation provides harder condition of being free. Thus, it metaphorically means that it needs enormous effort to be free. If the man can escape, it depicts the power he has.

The Attributes represented in this caricature is depicted from air bubbles around him also indicate that although he is in water, he still tries to survive, by holding his breath. Therefore, it provides symbolic meaning that he is not giving up.

\section{Verbal and Intersemotic Analysis}

From the verbal and visual elements, the intersemiotic relation can be captured. From table 13, it is clear that Setya Novanto is portrayed in both multimodal modes, giving repetition intersemiotic relation. Another interesting fact is that there is antonymy relation from the 
lexical item free and with the chain and handcuffs represented in the picture, having meaning of being jailed. In addition, the process of right hand move collocates with the lexical item strategy the movement, having connoting as the effort to escape.

Table 13 Ideational Intersemiotic Relation

\begin{tabular}{|c|c|c|c|c|c|}
\hline & \multicolumn{2}{|c|}{ Represented participants } & Process & Circumstances & Attributes \\
\hline S's & $\begin{array}{c}\text { Setya } \\
\text { Novanto }\end{array}$ & $\begin{array}{l}\text { chains and } \\
\text { handcuffs } \\
\text { (being jailed) }\end{array}$ & $\begin{array}{l}\text { right-hand } \\
\text { move } \\
\text { (effort escape } \\
\text { from prison) }\end{array}$ & $\begin{array}{l}\text { aqua colour } \\
\text { representing water } \\
\text { (being in hard } \\
\text { situation) }\end{array}$ & $\begin{array}{c}\text { air bubbles } \\
\text { (not giving } \\
\text { up to get } \\
\text { freedom) }\end{array}$ \\
\hline 1. & $\begin{array}{c}\text { Setya } \\
\text { Novanto } \\
\text { (R) }\end{array}$ & free $(A)$ & strategy $(\mathrm{C})$ & - & - \\
\hline
\end{tabular}

\section{Figure 5}

\section{Visual Analysis}

From this figure, the Identification is derived from a man caricatured as Setya Novanto, wearing a suit and a watch. He holds a smart phone in his left hand. The visual also illustrates the messages appearing on his screen that informs some people leaving the chatting group and makes Setya Novato as the administrator. Thus, it implies that his colleagues are no longer want to be connected with the case, demanding him to take sole responsibility. The Activity shown here is that he looks at his phone, a device symbolizing source of information. It describes that he receives information from the device, informing that his colleagues are leaving him. He also looks in surprised as his right hand covers his mouth with glaring eyes. The visual metaphor from this can be described as he shows surprised reaction as the impact of what he reads/sees from it. Thus, the information he got seems unpredicted

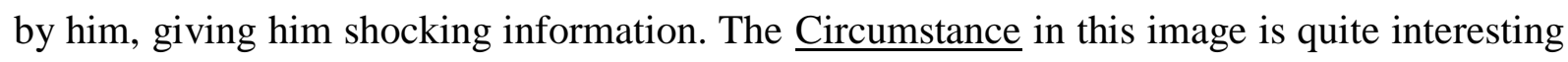
as it lacks of backgrounded setting considering the fact that the man is the only element in the picture, providing salience effect, without any other animate or inanimate participant. The lack of circumstantial aspect then serves to accentuate things shown in the display. The Attributes from this participant is the surprised emotion as explained from the way he covers his mouth. His fierce glared eyes also add the representation of being shock. In this case, the suit and watch he wears depicts the power and welfare of the man. 


\section{Verbal and Intersemiotic Analysis}

The verbal elements of this image are presented in Table 15. In this case, the lexical items of left group are mentioned three times, depicting more than one people sending the messages. Therefore, it can be interpreted that there are many people involved in his case. Concerning the last sentence, mandating the man who is called Papa as administrator, it indicates that the others do not want to deal with it anymore, deciding to leave the case and leaving the man behind. Thus, the man is the one responsible for it.

From Table 16, the intersemiotic relation between the multimodal modes can be analysed. In this case, the Activity is subsumed into Identification having the same interpretation. Setya Novanto in visual mode is being mentioned again in verbal mode as Setya representing intersemiotic repetition, and papa, having synonymy meaning of him. The lexical item left group and administrator commonly appears in messaging system in smartphone, giving collocation relation with the visual element of smartphone on the image.

Table 16 Ideational Intersemiotic Relation

\begin{tabular}{c|cc|c|c}
\hline & \multicolumn{2}{|c|}{ Represented participants } & \multicolumn{2}{c}{ Attributes } \\
\hline S's & $\begin{array}{c}\text { Setya } \\
\text { Novanto }\end{array}$ & $\begin{array}{c}\text { smart phone } \\
\text { (giving information) }\end{array}$ & $\begin{array}{c}\text { suit and watch } \\
\text { (power, wealth) }\end{array}$ & $\begin{array}{c}\text { expression } \\
\text { (surprised) }\end{array}$ \\
\hline 1. & - & left group (C) & - & - \\
\hline 2. & - & left group (C) & - & - \\
\hline 3. & Setya (R) & - & - & - \\
\hline 4. & - & left group (C) & - & - \\
\hline 5. & Papa (S) & administrator (C) & - & - \\
\hline
\end{tabular}

\section{Figure 6}

In this figure, the Identification representation is a crowd of people wearing various colours of suit and dress, like blue, yellow, orange, red, green, black, and white indeed representing various parties. The illustrator pictures the people as several politicians in Indonesia, including Setya Novanto (the focus of this study). The most salient participant is caricatured as Setya Novanto, as he stands in the centre, having frontal angle. The yellow suit he wears connoting to Golkar party. There are also cards represented in the picture carried by some of the people which are in broken condition because of literally being eaten by the people. The colour of the card is blue with red and white stripes on it, representing Indonesia's Electronic Identity Card. 
From the Activity, they are having conversation while laughing. However, there are two people pictured in black and white shirt on each top corner of the page who do not seem happy as the others do. In addition, they act as if they 'ate' the cards. It has metaphoric meaning as the project of Electronic Identity Card was corrupted by those people represented on the cover. The Circumstances in this text can be examined from the suit and dress they wear, referring to formal occasion, a kind of formal meeting or party attended by powerful people. The Attributes depicted here can be classified into two, the black and white men having neutral facial expression, while the others who wears colourful clothes show enthusiasm and joy.

\section{Verbal and Intersemiotic Analysis}

The intersemiotic relations shown in the last figure are shown in Table 19. The people on the cover page have collocation relation with the word legislators. The card representing Electronic Identity Card has intersemiotic repetition, in the first and second sentences. It also shows collocation in the lexical item program. The process of interacting and literally 'eating' the card depicted in the image shows collocation relation to the word were suspected, since the people involved were finally suspected. The visual circumstances in which described from the clothes they wear relates to the word party (occasion), showing collocation relation with the lexical item celebration in which written twice. This implies that the celebration is emphasized in the news, as it is pictured in visual and twice in verbal aspect.

Table 19 Ideational Intersemiotic Relation

\begin{tabular}{|c|c|c|c|c|}
\hline & \multicolumn{2}{|c|}{ Represented participants } & \multirow{2}{*}{$\begin{array}{c}\text { Process } \\
\text { interacting and eating } \\
\text { (involved in corrupting } \\
\text { the project) }\end{array}$} & \multirow{2}{*}{$\begin{array}{c}\text { Circumstances } \\
\text { suit and dress } \\
\text { (formal meeting/ } \\
\text { party) }\end{array}$} \\
\hline S's & $\begin{array}{c}\text { Several } \\
\text { people } \\
\text { (politicians) }\end{array}$ & $\begin{array}{c}\text { broken card } \\
\text { (Electronic Identity } \\
\text { Card) }\end{array}$ & & \\
\hline 1. & - & $\begin{array}{l}\text { Indonesia's Electronic } \\
\text { Identity Card (R) }\end{array}$ & - & celebration $(\mathrm{C})$ \\
\hline 2. & - & $\begin{array}{c}\text { Indonesia's Electronic } \\
\text { Identity Card (R) } \\
\text { program }(\mathrm{S})\end{array}$ & - & celebration $(\mathrm{C})$ \\
\hline 3. & $\begin{array}{l}\text { legislators } \\
\text { (S) }\end{array}$ & - & were suspected $(\mathrm{C})$ & - \\
\hline
\end{tabular}




\section{The Sketch Caricature}

\section{Setya Novanto}

One of the focal objectives of the caricature on the magazine's covers is the identification of participants involved in the captured image. It is clear that Setya Novanto is the main character in this case reflected from the frequent intersemiotic repetition of his name and intersemiotic synonym of papa and lexical item of me which have intersemiotic collocation.

The stance of this magazine is also seen from the Attributes which may seem unimportant aspect, like the suit he wears in almost every single cover connoting deeper meaning than it is actually seen. It seems that the publisher wants him to be pictured as a metaphorically powerful person who capable of dodging of what being accused. The authority he has depicted from the clothes he wears intersemiotically connotes to the lexical items, like disappeared, leaks, and insiders in which person having high position, wealth, and power is the one who is able to do that. Thus, it can be concluded that despite his trial status, the perception of this magazine towards him is as the one having power, connection and the one should take the responsibility towards the case being mentioned in Figure 6 which picture him having salience image among the other caricatured legislators.

\section{Other Parties}

This case seems involving many other parties as denotes in Figure 6, showing the visual of some people and intersemiotically relates to the word legislators (synonymy relation). Figure 5 certainly shows that he did not work alone regarding the case, but he needed colleagues to run the program as the visual shows a smart phone which have intersemiotic collocation with "left group" said by some group members. It also denotes that the colleagues with whom he used to work with were leaving him alone.

However, it seems that he has invincible power even some of his colleagues leaving him. In this case, he is able to make the other parties (Corruption Eradication Commission's chiefs) being charged with crime by the police because of trying to take him to court. Therefore, it can be generalized that even though mostly Setya is caricatured alone, being the salience without any other animate objects, it can be inferred that he is not alone in succeeding the project. Figure 1, for example, shows Setya as the only animate objects, but it has deeper 
meaning portrayed from the lexical item "insiders" which intersemiotically collocates with the suit he wears.

\section{CONCLUSION}

From the analysis above, it can be concluded that Tempo's magazine involves visual-verbal relations on its cover relating to Setya Novanto. The illustrator employs 56\%, the biggest scale, on intersemiotic collocation, reflecting expectancy relations. Considering the other relations, collocation seems holding the broader relations so that the readers can easily grasp the intended message from the multimodal. Thus, the use of this relation holds the biggest percentage. The second biggest relation is intersemiotic repetition, having $25 \%$. This indicates that the producer wants to accentuate the things being discussed. In this case, the repetition is mostly on the actor, Setya Novanto, emphasizing that he is the main focus of attention.

The image and text does not merely work separately. They work together in order to build uniform message, the combination of those multimodal modes allows the creators in completing the vision implied in the text (Goodnow, 2017). Besides, the combination of the multimodal modes is the best way in creating extended meaning since they are completing each other. Thus, it proves that the magazine illustrator designs the cover intentionally so that the relation between those multimodal elements, visual and verbal, can be identified by the readers.

\section{REFERENCES}

Abrahamson, D. A., Bowman, R. L., Greer, M. R., et al. (2003). A quantitative analysis of U.S. consumer magazines: A ten-year longitudinal study of transformation. Journal of Magazine and New Media Research 5(2): 1-65

Benson, P. J., Perrett, D., I. (1994). "Visual processing of facial distinctiveness" Perception $2375-93$

Dodd, D. K., Foerch, B. J., \& Anderson, H. T. (1988). Content analysis of women and racial minorities as news magazine cover persons. Journal of Social Behavior and Personality, 3, 231-236.

Goodnow, T. (2017) Signs of the Apocalypse: An Analysis of Trump Magazine Covers During the 2016 Presidential Campaign. American Behavioral Scientist. London: Sage

Halliday, M.A.K. (1994). An Introduction to Functional Grammar, 2nd edn. London: Arnold.

Jenkins, J., Tandoc, E. C. (2015). The Power of the Cover: Symbolic Contests around the Boston Bombing Suspect's Rolling Stone Cover. Journalism. Sage 
Kress, G., van Leeuwen, T. (2006). Reading images: The grammar of visual design. New York, NY: Routledge

Rhodes, G., Brennan, S., Carey, S., (1987). Identification and ratings of caricatures: Implications for mental representations of faces. Cognitive Psychology 19 473-497

Rhodes, G., Byatt, G., Tremewan, T., Kennedy, A. (1997). Facial Distinctiveness and The Power of Caricatures. Perception, 26, 207-223.

Rhodes, G., Tremewan, T. (1994). Understanding face recognition: Caricature effects, inversion and the homogeneity problem. Vision Cognition 1 275-311

Rosielle, L. J., Hite, L. A. (2009) The Caricature Effect in Drawing: Evidence for the Use of Categorical Relations When Drawing Abstract Pictures. Perception, 38, 357-75

Royce, T. (1998). Synergy on the page: Exploring intersemiotic complementarity in pagebased multimodal text. JASFL Occasional Papers, 1, 25-49.

Royce, T. (1999). Visual-verbal intersemiotic complementarity in The Economist magazine. Unpublished doctoral dissertation, University of Reading, England

Royce, T. (2002). Multimodality in the TESOL Classroom: Exploring Visual-Verbal Synergy. TESOL Quarterly.

Royce, T. (2015). Intersemiotic Complementarity in Legal Cartoons: An Ideational Multimodal Analysis. International Journal for the Semiotics of Law

Tseronis, A. (2015). Multimodal argumentation in news magazine covers: A case study of front covers putting Greece on the spot of the European economic crisis. Discourse, Context \& Media, 7, 18-27. 